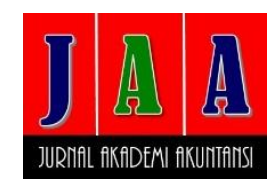

\title{
PENGARUH PENERBITAN SURAT PAKSA DAN SURAT PERINTAH PENYITAAN TERHADAP PENERIMAAN PPh Pasal 25 WAJIB PAJAK ORANG PRIBADI
}

(Studi Empiris pada Kantor Pelayan Pajak Pratama Gresik Utara pada tahun 2015 - 2017)

\author{
Arslinda Dwi Pratiwi *, Setu Setyawan \\ Program Studi Akuntansi Fakultas Ekonomi dan Bisnis \\ Universitas Muhammadiyah Malang \\ Jl. Raya Tlogomas No. 246 Malang \\ *Corresponding author: arslindadwip@gmail.com
}

\begin{abstract}
Tax receipts are one source of income that has a major impact on the prosperity and welfare of the community. In 2016, $81.75 \%$ of the country's revenues come from taxes. There is a decrease in the amount of income tax article 25 WP-OP, in 2016 amounted to $36.12 \%$ led to reduced tax revenue. One of the things that most influence the income tax is the tax audit that generates tax assessment letters and tax collection. This study purpose to examine the effect of Issuance of forced letter and confiscation warrant on Income Tax Article $25 \mathrm{WP}-\mathrm{OP}$. in this research is KPP Pratama Gresik Utara in 2015-2017. In this study, the sample amounted to 35 by using multiple linear regression analysis techniques. The results showed that simultaneous issuance of forced letter and confiscation warrant have a significant effect on Income Tax Article 25 WP-OP
\end{abstract}

Keywords: Forced Letter, Confiscation Warrant, and Income Tax Article 25.

\section{PENDAHULUAN}

Pada tahun 2016 pencapaian strategis Direktorat Jenderal Pajak tercermin dalam realisasi penerimaan pajak yang mencapai Rp1.105,81 triliun atau 81,75\% dari target APBN-P tahun 2016 (Laporan Kinerja Dirjen Pajak, 2017).

Pemerintah berusaha mengoptimalkan dan meningkatkan penerimaan pajak dengan melakukan pengawasan terhadap self assessment system melalui pemeriksaan pajak yang menghasilkan Surat Ketetapan Pajak (SKP) dan penagihan pajak, sesuai dengan undang-undang no.28 tahun 2007 sebagai tindakan untuk melakukan pengawasan terhadap self assessment system Dirjen Pajak berwenang melakukan pemeriksaan pajak untuk menerbitkan Surat Ketetapan Pajak (SKP) yang selanjutnya akan dilakukan penagihan pajak

Diterima 14 Sep 2018

Direviu 20 Sep 2018

Direvisi 12 Okt 2018

Diterima 22 Okt 2018

Artikel ini tersedia di website :

http://ejournal.umm. ac.id/index.php/jaa terhadap wajib pajak yang dinyatakan tidak atau kurang bayar. Surat Ketetapan Pajak (SKP) timbul jika adanya ketidak benaran atau ada data fiskal yang tidak dilaporkan oleh Wajib Pajak, sehingga menyebabkan kesalahan pada laporan.

Faktor atau tindakan lain yang dilakukan pemerintah guna untuk meningkatkan penerimaan pajak yaitu dengan penagihan pajak, penagihan pajak merupakan tindakan yang dilakukan kantor pajak guna untuk menegur atau menagih wajib pajak agar segera melunasi utang pajaknya. Salah satu sumber penerimaan pajak lainnya yaitu penerimaan PPh pasal 25, Menurut Undang- 
Undang No 36 Tahun 2008 PPh Pasal 25 adalah besarnya angsuran pajak penghasilan dalam tahun berjalan.

Dalam realisasi penerimaan pajak penghasilan non migas terutama $\mathrm{PPh}$ pasal 25 orang pribadi mencapai 5.275,17 miliar (18,32\%), penerimaan $\mathrm{PPh}$ pasal 25 Orang Pribadi tahun 2016 mengalami penurunan sebesar 36,12\% jika dibandingkan dengan tahun sebelumnya (Laporan Kinerja Dirjen Pajak, 2016). Hal itu bisa terjadi dikarenakan penerbitan surat paksa dan surat penyitaan yang dilakukan oeleh kantor pajak. Surat paksa berpengaruh apabila di tahun berjalan wajib pajak tidak atau kurang bayar pajak maka akan dilakukan penagihan pajak. Penagihan yng diberikan kepada wajib pajak adalah penagihan pajak pasif yang diberi waktu 1 bulan untuk melunasi. Apabila dalam waktu 1 bulan dan belum dilunasi maka 7 (tujuh) hari kemudian diterbitkanlah surat teguran. Surat teguran memiliki jangka waktu 21 (dua puluh satu) hari, ketika selama 21 (dua puluh satu) hari belum dilunasi juga maka diterbitkan surat paksa. Surat paksa memiliki jangka waktu 2 x 24 jam, apabila lebih dari batas waktu yang telah ditentutakan wajib pajak belum melunasi hutang hutang pajaknya maka akan dilakukan penyitaan.

Berdasarkan uraian tersebut maka peneliti tertarik untuk melakukan penelitian mengenai "Pengaruh Penerbitan Surat Paksa dan Surat Perintah Penyitaan Terhadap Penerimaan PPh Pasal 25 WP-OP”.

\section{PENGEMBANGAN HIPOTESIS}

\section{Pengaruh Penerbitan Surat Paksa terhadap Penerimaan Pajak Penghasilan Pasal 25 Wajib Pajak Orang Pribadi}

Berdasarkan Undang-undang Penagihan Pajak dengan Surat Paksa (PPSP) No.19 tahun 2000 dalam pasal 1 ayat (12) disebutkan bahwa Surat paksa memiliki kekuatan hukum yang tetap atau pasti dan tidak dapat ditentang, Sehingga Setiap kenaikan atau penurunan tindakan penagihan pajak aktif akan berpengaruh baik meningkatkan atau menurunkan pencairan tunggakan pajak sesuai dengan Derlina (2013) menyatakan bahwa penagihan pajak dengan surat paksa dikategorikan efektif terhadap penerimaan tunggakan pajak. Hendrawan (2013) menyatakan bahwa penagihan pajak dengan surat paksa berpengaruh signifikan.

H1 : Penerbitan surat paksa berpengaruh positif terhadap penerimaan Pajak Penghasilan pasal 25 Wajib Pajak Orang Pribadi.

Pengaruh Penerbitan Surat Perintah penyitaan terhadap Penerimaan Pajak Penghasilan Pasal 25 Wajib Pajak Orang Pribadi

Menurut Undang-undang No.19 tahun 2000, Surat penyitaan merupakan serangkaian tindak lanjut dari Surat Paksa, yang mana apabila dalam waktu $2 \mathrm{x}$ 24 jam Wajib Pajak tidak melunasi hutang pajaknya, maka diterbitkan Surat Perintah Melaksanakan Penyitaan. Rifqiansyah (2014) menyatakan bahwa penagihan pajak dengan surat penyitaan berpengaruh efektif terhadap pencairan tunggakan pajak. Ketika wajib pajak dalam waktu 21 hari tidak melakukan pembayran pajak sesuai dengan yang ada di dalam surat paksa maka akan dilakukan penyitan, dimana ketika penyitaan dilakukan wajib pajak akan dikenakan biaya sebesar Rp 100.000,00 (Seratus ribu rupiah) sehingga menyebabkan beban yang harus dibayar oleh wajib pajak akan semakin besar, 
dan wajib pajak tidak memiliki pilihan lain selain harus membayar hutang pajaknya. Karena jika tidak membayar hutang pajaknya maka barang milik wajib pajak yang disita oleh petugas pajak akan di lelang sesuai dengan peraturan yang berlaku.

H2 : Penerbitan surat perintah penyitaan berpengaruh positif terhadap penerimaan $\mathrm{PPh}$ pasal 25 wajib pajak orang pribadi.

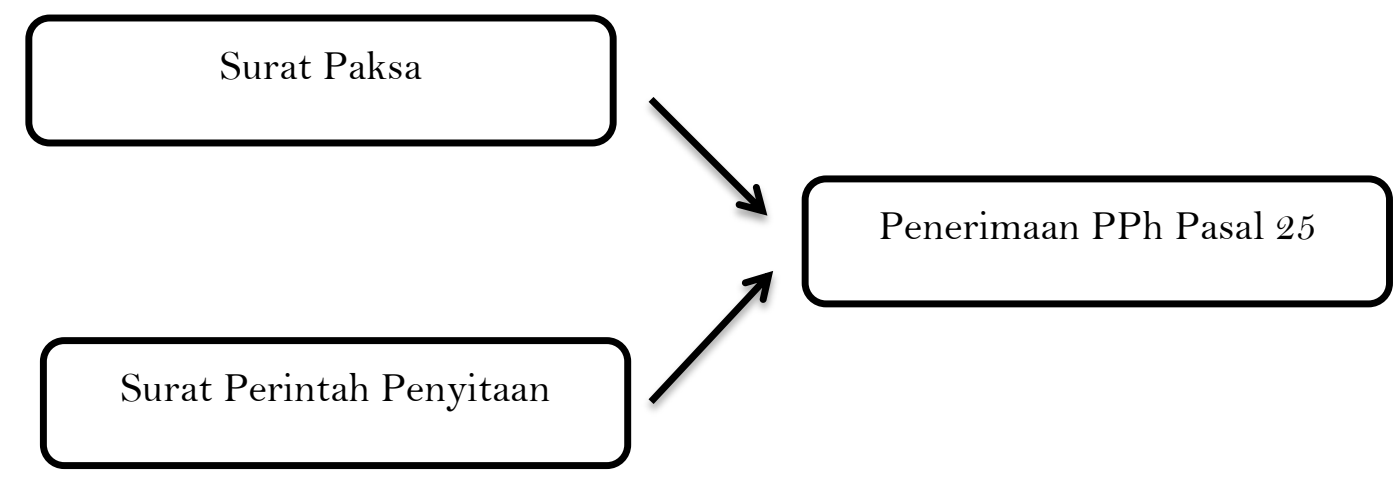

\section{Gambar 1. Rancangan Penelitian}

\section{METODE}

1. Jenis penelitian yang digunakan dalam penelitian ini adalah penelitian asosiatif yang digunakan untuk meneliti pengaruh atau hubungan antara variabel bebas (Surat Paksa dan Surat Perintah Penyitaan) dan variabel terikat (Penerimaan PPh Pasal 25).

2. Definisi Operasional dan Pengukuran Variabel

- Surat Paksa

Surat paksa meruakan surat yang diterbitkan oleh fiskus apabila wajib pajak dalam tahun berjalan kurang bayar atau tidak membayar kewajiban perpajakannya. Nilai nominal pada surat paksa setiap wajib pajak berbeda-beda, dikarenakan oleh besarnya hutang pajak atau tunggakan pajak, sanksi administrasi perpajakan, dan biaya penerbitan surat paksa. Diukur dengan jumlah surat paksa tahun 2015-2017 per bulan di Kantor Pelayanan Pajak Pratama Gresik Utara.

\section{Surat Perintah Penyitaan}

Penyitaan adalah tindakan yang dilakukan oleh jurusita pajak untuk menguasai barang milik wajib pajak atau penanggung pajak, yang digunakan jaminan untuk melunasi hutang pajaknya. Surat penyitaan merupakan serangkaian tindak lanjut dari Surat Paksa, yang mana apabila dalam waktu $2 \mathrm{x}$ 24 jam Wajib Pajak tidak melunasi hutang pajaknya, maka diterbitkan Surat Perintah Melaksanakan Penyitaan. Diukur dengan jumlah surat perintah penyitaan tahun 2015-2017 per bulan di Kantor Pelayanan Pajak Pratama Gesik Utara.

- Penerimaan PPh Pasal 25

Pajak Penghasilan Pasal 25 adalah angsuran pajak penghasilan dalam tahun berjalan. Dalam PPh Pasal 25 ini setiap wajib pajak memiliki jumlah angsuran yang berbeda-beda. Hal itu dikarenakan oleh besarnya pendapatan atau omset yang diperoleh wajib pajak. Selain itu, adanya surat ketetapan pajak yang 
diterbitkan dalam tahun berjalan akan mempengaruhi angsuran yang harus dibayarkan oleh wajib pajak di bulan selanjutnya. Diukur dengan jumlah penerimaan PPh Pasal 25 Wajib Pajak Orang Pribadi tahun 2015-2017 per bulan di Kantor Pelayanan Pajak Pratama Gresik Utara.

3. Jenis dan Sumber Data

Jenis data yang digunakan dalam penelitian ini yaitu data sekunder yaitu data yang diperoeh secara tidak langsung melalui media perantara berupa surat paksa, surat perintah penyitaan dan jumlah penerimaan PPh pasal 25 orang pribadi tahun 2015-2017 per bulan

4. Teknik Pengumpulan Data

Teknik yang digunakan untuk pengumpulan data dalam penelitian ini yaitu dokumentasi, data yang diperoleh dari hasil dokumentasi adalah jumlah surat paksa, surat perintah penyitaan dan jumlah penerimaan $\mathrm{PPh}$ pasal $25 \mathrm{WP}$ OP di KPP Pratama Gresik Utara.

5. Teknik Analisis Data

Metode analsis yang digunakan dalam penelitian ini adalah analisis deskriptif, uji asumsi klasik dengan uji normalitas, uji autokorelasi, dan uji multikolinieritas. Data diolah dengan menggunakan SPSS. Selanjutnya analisis regresi linier berganda dengan melakukan uji $\mathrm{F}$, uji $\mathrm{t}$ dan uji koefisien determinasi untuk membuktikan apakah terdapat pengaruh antara variabel bebas (Surat Paksa dan SuratPErintah Penyitaan) terhadap variabel terikat (Penerimaan PPh Pasal 25).

\section{HASIL DAN PEMBAHASAN}

\section{Analisis Deskriptif}

\begin{tabular}{llllll}
\hline & N & Minimum & Maximum & Mean & $\begin{array}{l}\text { Std. } \\
\text { Devitiation }\end{array}$ \\
\hline $\begin{array}{l}\text { Surat } \\
\text { Paksa }\end{array}$ & 35 & 17.00 & 555.00 & 221.94 & 139.31 \\
SPP & 35 & .00 & & & \\
PPh Pasal & 35 & 111690859.00 & 902133417.00 & 368558563.94 & 141457378.93 \\
$\begin{array}{l}\text { 25 } \\
\text { Valid N }\end{array}$ & 35 & & & & \\
(listwise) & & & & & \\
\hline
\end{tabular}

Berdasarkan tabel di atas menunjukkan jumlah sampel yag digunakan adalah sebanyak 36 sampel dan dapat diuraikan seperti berikut:

1. Variabel Surat Paksa $\left(\mathrm{X}_{1}\right)$ memiliki nilai minimum 17 dan nilai maksimum 555. Secara keseluruhan, kisaran rata-rata yang diperoleh adalah 221.94 dengan besar simpangan 139.31. Berdasarkan data yang diperoleh dari KPP Pratama Gresik Utara, nilai maksimum penerbitan Surat Paksa terjadi pada bulan Agustus tahun 2015 sebanyak 555 lembar dan nominal surat paksa terbesar pada Juni tahun 2016 sebesar Rp 18.398.510.092. Sedangkan nilai minimum penerbitan Surat Paksa terjadi pada bulan Desember tahun 2016 sebanyak 17 lembar dan nominal surat paksa terkecil terjadi pada bulan September tahun 2015 sebesar Rp 6.750.000. 
2. Variabel Surat Perintah Penyitaan $\left(\mathrm{X}_{2}\right)$ memiliki nilai minimum o dan nilai maksimum 26. Secara keseluruhan, kisaran rata-rata yang diperoleh adalah 3.17 dengan besar simpangan 5.87. Berdasarkan data yang diperoleh dari KPP Pratama Gresik Utara, nilai maksimum penerbitan Surat Perintah Penyitaan terjadi pada bulan November 2015 sebanyak 26 lembar dan nominal Surat Perintah Penyitaan terbesar terjadi pada bulan November 2017 sebesar Rp 34.570.306.148. Sedangkan nilai minimum penerbitan Surat Perintah Penyitaan sebanyak o lembar dan nominal Surat Perintah Penyitaan terkecil sebesar Rp O.

3. Variabel Penerimaan PPh Pasal 25 (Y) memiliki nilai minimum 111690859 dan nilai maksimum 902133417. Secara keseluruhan, kisaran rata-rata yang diperoleh adalah 368558563.94 dengan besar simpangan 141457378.93. berdasarkan data yang diperoleh dari KPP Pratama Gresik Utara, nilai maksimal penerimaan PPh pasal 25 terjadi pada bulan Desember tahun 2015 sebesar Rp 902.133.417. Sedangkan nilai minimum terjadi pada bulan April tahun 2017 sebesar Rp 111.690.859. Secara keseluruhan Rata-rata yang diperoleh adalah sebesar Rp 372.261.508 dengan besar simpangan sebesar Rp 141.181 .071 .

\section{Uji Asumsi Klasik}

\section{a. Uji Normalitas}

Uji asumsi normalitas bertujuan untuk menguji apakah residual dalam model regresi mengikuti sebaran normal atau tidak (Ghozali, 2016;154). Metode dalam menguji normalitas dilakukan dengan menggunakan uji statistik KolmogorovSmirnov. Residual model dikatakan mengikuti distribusi normal apabila nilai signifikansi Kolmogorov-Smirnov bernilai lebih besar dari 0.05. Hasil pengujian disajikan sebagai berikut :

Tabel 4.5 Hasil Uji Kolmogorov-Smirnov

\section{One-Sample Kolmogrov-Smirnov Test}

\begin{tabular}{lll}
\hline & & $\begin{array}{l}\text { Unstandadized } \\
\text { Residual }\end{array}$ \\
\hline $\mathbf{N}$ & Mean & 35 \\
& & oE-7 \\
Normal Parameters ${ }^{\text {a.b }}$ & & 70849282.5499 \\
& Std. Deviation & 0363 \\
& Absolute & .177 \\
Most Extreme Differences & Positive & .177 \\
& Negative & -.144 \\
Kolmogrov-Smirnov Z & & 1.049 \\
Asymp. Sig. (2-tailed) & & .221 \\
\hline
\end{tabular}

a. Test distribution is Normal

b. Calculated from data.

\begin{tabular}{lll}
\hline Variabel & Signifikansi & Keterangan \\
\hline
\end{tabular}




\begin{tabular}{lll}
\hline Residual Model (e) & 0,221 & Normal \\
\hline
\end{tabular}

Berdasarkan tabel tersebut diperoleh nilai signifikansi uji Kolmogorov-Smirnov sebesar 0,221 >0,05 sehingga diputuskan Terima $\mathrm{H}_{0}$, yang artinya data berdistribusi normal.

\section{b. Uji Autokorelasi}

Uji autokorelasi digunakan untuk mengetahui apakah terdapat korelasi antara kesalahan penganggu pada periode $t$ dengan kesalahan pengganggu pada periode t-1 (sebelumnya). Regresi yang baik adalah regresi yang residualnya saling bebas. Untuk mengetahui ada tidaknya autokorelasi pada residual digunakan ujivariabel bebas $=2$ dan $n=35$ meghasilkan $d u=1,5838$ sehingga 4-du $=2,416$. Hasil regresi dikatakan terpenuhi asumsi autokorelasinya jika 1,5838< DW < 2,416. Berikut adalah hasil pengujian autokorelasi yang diperoleh dari software SPSS 23.

\section{Tabel 4.6 Hasil Uji Autokorelasi}

Model Summary

\begin{tabular}{llllll}
\hline Model & $\mathbf{R}$ & R Square & $\begin{array}{l}\text { Adjusted R } \\
\text { Square }\end{array}$ & $\begin{array}{l}\text { Std. Error of } \\
\text { the Estimate }\end{array}$ & $\begin{array}{l}\text { Durbin- } \\
\text { Watson }\end{array}$ \\
\hline $\mathbf{1}$ & $.866^{\mathrm{a}}$ & .749 & .733 & 73029768.86 & 2.318 \\
\hline a. & Predictors: (Constant), Surat Perintah Penyitaan, Surat Paksa &
\end{tabular}

Predictors: (Constant), Surat Perintah Penyitaan, Surat Paks

b. Dependent Variable: PPh Pasal 25

\begin{tabular}{lll}
\hline Variabel & DW & Keterangan \\
\hline Residual Model (e) & 2,318 & Non Autokorelasi \\
\hline
\end{tabular}

Berdasarkan tabel di atas dapat diketahui bahwa nilai DW yang diperoleh adalah 2,318. Nilai tersebut terletak di antara batas yang ditentukan sehingga asumsi autokorelasi terpenuhi. 


\section{c. Uji Multikolinearitas}

Uji multikolinearitas bertujuan untuk mengetahui adanya hubungan linear antara variabel - variabel bebas dalam model regresi. Dalam pengertian lain asumsi non multikolinearitas adalah bahwa setiap variabel bebas (prediktor) hanya berpengaruh pada variabel respon dan bukan pada variabel bebas lainnya Pada uji ini diharapkan tidak terjadi multikolinearitas dimana antara variabel independen dan model regresi tidak berhubungan secara sempurna atau mendekati sempurna yang dapat diketahui dengan cara melihat nilai Variance Inflation Factor (VIF) pada masing - masing variabel bebas. Apabila nilai VIF > 10 maka $\mathrm{H}_{0}$ ditolak yang menunjukkan adanya multikolinieritas dan sebaliknya apabila sebaliknya VIF $<10$ maka $\mathrm{H}_{0}$ diterima yang menunjukkan tidak terjadi multikolinieritas. Berikut adalah hasil pengujian asusmi non multikolinearitas.

Tabel 4.7 Hasil Pengujiam Multikolinieritas dengan Nilai VIF

\section{Coefficients $^{\mathrm{a}}$}

\begin{tabular}{|c|c|c|c|c|c|}
\hline \multirow[t]{2}{*}{ Model } & \multicolumn{2}{|c|}{$\begin{array}{l}\text { Unstandardized } \\
\text { Coefficients }\end{array}$} & \multirow{2}{*}{$\begin{array}{l}\text { Standardized } \\
\text { Coefficients } \\
\text { Beta }\end{array}$} & \multicolumn{2}{|c|}{$\begin{array}{l}\text { Collinearity } \\
\text { Statistics }\end{array}$} \\
\hline & $\mathrm{B}$ & Std. Error & & Tolerance & VIF \\
\hline 1 (Constant) & 247822797.36 & 23926967.128 & & & \\
\hline SP & 318348.08 & 106592.61 & .314 & .711 & 1.406 \\
\hline SPP & 15791206.38 & 2528321.39 & .656 & .711 & 1.406 \\
\hline
\end{tabular}

a. Dependent Variable : PPh Pasal 25

\begin{tabular}{llll}
\hline Variabel Terikat & Variabel Bebas & VIF & Keterangan \\
\hline PPh Pasal 25 & Surat Paksa & 1,406 & Bebas Multikol \\
& Surat Perintah & 1,406 & Bebas Multikol \\
& Penyitaan & & \\
\hline
\end{tabular}

Berdasarkan tabel hasil pengujian multikolinieritas, dapat diketahui bahwa pada variabel bebas Surat Paksa $\left(\mathrm{X}_{1}\right)$ diperoleh nilai VIF 1,406 dan Surat Perintah Penyitaan sebesar 1,406. Semua variabel bebas memiliki nilai VIF < 10, sehingga dalam model ini tidak terjadi multikolinearitas.

\section{Analisis Regresi Linier Berganda}

pengolahan data analisis regresi berganda "Pengaruh Penerbitan Surat Paksa dan Surat Perintah Penyitaan Terhadap Penerimaan PPh Pasal 25 WP-OP pada KPP Pratama Gresik Utara Tahun 2015-2017" diperoleh hasil seperti pada tabel berikut:

Tabel 4.8 Hasil Analisis Regresi

\begin{tabular}{llllll}
\hline $\begin{array}{l}\text { Variabel } \\
\text { Terikat }\end{array}$ & $\begin{array}{l}\text { Variabel } \\
\text { Bebas }\end{array}$ & B & thitung $_{\text {ignifikan }}$ & Keterangan \\
\hline PPh & Konstanta & 247822797.36 & & & \\
Pasal 25 & Surat Paksa & 318348.08 & 2.987 & 0,005 & Signifikan \\
& Surat Perintah & 15791206.38 & 6.246 & 0,000 & Signifikan \\
& Penyitaan & & & & \\
F & 47.782 & & & & \\
hitung & & & & & \\
\hline
\end{tabular}




\begin{tabular}{lll}
\hline Sig & Uji & 0,000 \\
$\mathbf{F}$ & & \\
$\boldsymbol{\alpha}$ & $5 \%$ \\
$\mathbf{R}^{2}$ & 0,749 \\
\hline
\end{tabular}

Dari tabel diatas diperoleh model regresi sebagai berikut :

Penerimaan $\mathrm{PPh}=247822797.36+318348.08$ Surat Paksa +15791206.38 Surat Perintah Penyitaan.

- Pengujian Hipotesis Secara Simultan (Uji F)

Uji F dilakukan untuk menentukan apakah semua variabel yang digunakan dalam model regresi memiliki pengaruh yang signifikan terhadap Ysecara bersama-sama. Hipotesis yang digunakan dalam pengujian adalah sebagai berikut:

$\mathrm{H}_{\mathrm{o}}$ : Tidak terdapat pengaruh yang signifikan antara Surat Paksa $\left(\mathrm{X}_{1}\right)$ dan Surat Perintah Penyitaan $\left(\mathrm{X}_{2}\right)$ terhadap PPh Pasal $25(\mathrm{Y})$ secara bersam-sama.

$\mathrm{H}_{1}$ : Terdapat pengaruh yang signifikan antara Surat Paksa $\left(\mathrm{X}_{1}\right)$ dan Surat Perintah Penyitaan $\left(\mathrm{X}_{2}\right)$ terhadap PPh Pasal 25 (Y) secara bersam-sama

Tabel 4.9 Hasil Uji Simultan (F-test)

ANOVA $^{a}$

\begin{tabular}{lllllll}
\hline Model & Sum & of & Df & Mean Square & F & Sig. \\
& & Squares & & & & \\
\hline $\mathbf{1}$ & Regression & 5096793533760 & 2 & 2548396766880 & 47.782 & $.000^{\mathrm{b}}$ \\
& & 66750.00 & & 33376.000 & & \\
& \multirow{2}{*}{ Residual } & 1706671084864 & 32 & 5333347140200 & & \\
& & & & & \\
\multirow{2}{*}{ Total } & 67360.000 & & 855.00 & & \\
& 9803464618624 & 34 & & & \\
& 94080.000 & & & & \\
\hline
\end{tabular}

a. Dependent Variable:PPh Pasal 25

b. Predictors: (Constant), Surat Perintah Penyitaan, Surat Paksa

Berdasarkan tabel, nilai $\mathrm{F}$ hitung yang diperoleh adalah 47.782 dan sig $\mathrm{F}$ $=0,000$. Karena nilai sig $\mathrm{F}<0.05$ maka diputuskan tolak $\mathrm{H}_{0}$ yang berarti bahwa terdapat pengaruh yang signifikan antara Surat Paksa $\left(\mathrm{X}_{1}\right)$ dan Surat Perintah Penyitaan $\left(\mathrm{X}_{2}\right)$ terhadap PPh Pasal $25(\mathrm{Y})$ secara bersam-sama

- Pengujian Hipotesis Secara Parsial (Uji t)

Uji parsial digunakan untuk mengetahui ada tidaknya pengaruh variabel bebas terhadap variabel terikat secara individual. Setelah diketahui bahwa tidak terdapat pengaruh variabel bebas secara simultan terhadap PPh Pasal 25 maka secara tidak langsung juga hasil uji parsial akan menghasilkan hasil yang tidak signifikan seperti uraian berikut :

\section{Coefficients $^{\mathrm{a}}$}

\begin{tabular}{|c|c|c|c|c|c|}
\hline \multirow[t]{2}{*}{ Model } & & Coefficients & $\begin{array}{l}\text { Standardized } \\
\text { Coefficients }\end{array}$ & $\mathrm{t}$ & \multirow[t]{2}{*}{ Sig. } \\
\hline & $\bar{B}$ & Std. Error & Beta & & \\
\hline
\end{tabular}




\begin{tabular}{lllllll}
\hline 1 & (Constant) & 247822797.365 & 23926967.128 & & 10.357 & .000 \\
& $\begin{array}{l}\text { Surat } \\
\text { Paksa }\end{array}$ & 318348.085 & 106592.610 & .314 & 2.987 & .005 \\
& & & & & \\
& $\begin{array}{l}\text { Surat } \\
\text { Perintah }\end{array}$ & 15791206.389 & 2528321.391 & .656 & 6.246 & .000 \\
& & & & & \\
\hline
\end{tabular}

a. Dependent Variable: PPh Pasal 25

- Variabel Surat Paksa $\left(\mathrm{X}_{1}\right)$

Berdasarkan tabel di atas diperoleh $\mathrm{t}$ hitung $=2,987$ dan sig $\mathrm{t}$ sebesar 0,005. Nilai sig $\mathrm{t}<0,05$ menunjukkan bahwa $\mathrm{H}_{0}$ ditolak yang menunjukkan bahwa Surat Paksa berpengaruh signifikan terhadap PPh Pasal 25. Koefisien dari $\beta_{1}=318348.085$ Nilai ini dapat diartikan bahwa jika surat paksa meningkat 1 maka PPh pasal 25 akan meningkat pula sebesar 318348.085.

- Variabel Surat Perintah Penyitaan $\left(\mathrm{X}_{2}\right)$

Berdasarkan tabel di atas diperoleh $\mathrm{t}$ hitung $=6.246$ dan sig $\mathrm{t}$ sebesar 0,000. Nilai sig $\mathrm{t}<0,05$ menunjukkan bahwa $\mathrm{H}_{0}$ ditolak yang menunjukkan bahwa Surat Perintah Penyitaan berpengaruh signifikan terhadap PPh Pasal 25. Koefisien dari $\beta_{1}=15791206.389$ memiki makna jika surat perintah penyitaan meningkat 1 maka PPh pasal 25 akan meningkat pula sebesar 15791206.389.

a. Koefisien Determinasi

Koefisien determinasi $\left(R^{2}\right)$ merupakan besaran yang memberikan informasi goodnes of fit dari persamaan regresi, yaitu memberikan proporsi atau presentase kekuatan pengaruh variabel Surat Paksa $\left(\mathrm{X}_{1}\right)$ dan Surat Perintah Penyitaan $\left(\mathrm{X}_{2}\right)$ terhadap PPh Pasal 25 (Y).

Model Summary

\begin{tabular}{llllll}
\hline Model & R & R Square & $\begin{array}{l}\text { Adjust } \\
\text { Square }\end{array}$ & $\begin{array}{l}\text { Std. Error of } \\
\text { the Estimate }\end{array}$ & $\begin{array}{l}\text { Durbin- } \\
\text { Watson }\end{array}$ \\
\hline $\mathbf{1}$ & $.868^{\mathrm{a}}$ & .749 & .733 & 73029768.86312 & .2318 \\
\hline a. & Predictors: (Constant), Surat Perintah Penyitaan, Surat Paksa & \\
b. & Dependent Variable: PPh Pasal 25
\end{tabular}

Berdasarkan tabel hasil analisis regresi diperoleh nilai $R^{2}$ sebesar 0,749. Hasil tersebut menjelaskan sumbangan atau kontribusi dari variabel-variabel bebas dalam mempengaruhi variabel Y adalah sebesar 74,9\%, sedangkan 15,1\% lainnya disumbangkan oleh variabel lainnya yang tidak dimasukkan ke dalam persamaan ini.

\section{PEMBAHASAN}

1. Pengaruh Surat Paksa terhadap Penerimaan PPh Pasal 25

Hasil penelitian ini menunjukkan bahwa penagihan pajak dengan surat paksa berpengaruh signifikan terhadap penerimaan $\mathrm{PPh}$ pasal 25 di Kantor Pelayanan Pajak Pratama Gresik Utara pada tahun 2015-2017 dikarenakan surat paksa memiliki kekuatan eksekutorial dan kekuatan hukum yang sama dengan putusan pengadilan yang telah mempunyai kekuatan hukum yang tetap sesuai dengan Undang-Undang Nomor 19 tahun 2000 mengenai penagihan pajak dengan surat paksa. Sehingga dengan diterbitkannya surat paksa mengakibatkan 
kenaikan pada penerimaan yang diterima oleh KPP Pratama Gresik Utara. Dalam penelitian ini menunjukkan bukti bahwa thitung untuk variabel Surat Paksa $\left(\mathrm{X}_{1}\right)$ terhadap penerimaan $\mathrm{PPh}$ pasal $25(\mathrm{Y})$ menunjukkan 2,987, sedangkan tingkat signifikan 0,005 maka hal ini membuktikan bahwa penagihan pajak dengan surat paksa mempunyai pengaruh yang signifikan terhadap kepatuhan wajib pajak. Koefisien dari $\beta_{1}=318348.085$ Nilai ini dapat diartikan bahwa jika surat paksa meningkat 1 maka $\mathrm{PPh}$ pasal 25 akan meningkat pula sebesar 318348.085. Jadi, setiap penerbitan 1 lembar Surat Paksa akan menambah penerimaan sebesar Rp 318.348,08

Hasil penelitian ini juga mendukung hasil penelitian sebelumnya yang dilakukan oleh Hendrawan (2014) yang menunjukkan hasil yang signifikan dimana setelah wajib pajak mendapatkan penagihan pajak dengan surat paksa maka wajib pajak akan melakukan kewajiban pajaknya.

2. Pengaruh Surat Perintah Penyitaan terhadap Penerimaan PPh Pasal 25

Hasil penelitian ini menunjukkan bahwa penagihan pajak dengan surat perintah penyitaan berpengaruh signifikan terhadap penerimaan $\mathrm{PPh}$ pasal $25 \mathrm{di}$ Kantor Pelayanan Pajak Pratama gresik Utara pada tahun 2015-2017. Tingkat efektivitas Surat Perintah Penyitaan lebih besar jika dibandingkan dengan Surat Paksa, Hal ini dikarenakan surat perintah penyitaan merupakan tindak lanjut yang dilakukan oleh Kantor Pelayanan Pajak (KPP) Pratama ketika wajib pajak tidak melunasi kewajiban perpajakannya walaupun tela diterbitkannya surat paksa. Surat penyitaan nantinya akan digunakan oleh juru sita untuk melakukan penyitaan atau pengambil alihan terhadap barang bergerak maupun tidak bergerak yag sesuai dengan ketentuan undan-undang perpajakan untuk dilakukan tidankan lebih lanjut yaitu pelelangan dimana penjualan yang diperoleh akan digunakan untuk pembayaran utang pajaknya, pernyataan ini sesuai dengan Undang-Undang Nomor 19 tahun 2000 tentang penagihan pajak dengan surat paksa, sehingga wajib pajak tidak punya kekuasaan akan barang tersebut. Dalam penelitian ini menunjukkan bukti bahwa thitung untuk variabel Surat Perintah Penyitaan $\left(\mathrm{X}_{2}\right)$ terhadap penerimaan $\mathrm{PPh}$ pasal 25 (Y) menunjukkan 6,246, sedangkan tingkat signifikan 0,000 maka hal ini membuktikan bahwa penagihan pajak dengan surat perintah penyitaan mempunyai pengaruh yang signifikan terhadap kepatuhan wajib pajak. Koefisien dari $\beta_{1}=15791206.389$ memiki makna jika surat perintah penyitaan meningkat 1 maka PPh pasal 25 akan meningkat pula sebesar 15791206.389. Sehingga setiap penerbitan 1 surat perinatah penyitaan akan menambah penerimaan sebesar $\mathrm{Rp}$ 15.791.206.

Hasil penelitian ini mendukung hasil penelitian sebelumnya yang dilakukan Rudi (2013) menyatakan bahwa penagihan pajak aktif dengan surat penyitaan berpengaruh signifikan terhadap penerimaan pajak.

\section{SIMPULAN}

Berdasarkan hasil penelitian dan pembahasan analisis yang dilakukan mengenai pengaruh penerbitan surat paksa dan surat perintah penyitaan terhadap penerimaan $\mathrm{PPh}$ pasal $25 \mathrm{WP}-\mathrm{OP}$.

maka diperoleh kesimpulan bahwa Surat Paksa berpengaruh signifikan terhadap penerimaan PPh Pasal 25 WP-OP pada KPP Pratama Gresik Utara 
yang ditunjukkan dalam hasil Nilai sig 0,005 $<0,05$ menunjukkan bahwa Penerbitan Surat Paksa berpengaruh signifikan terhadap Penerimaan PPh Pasal 25 WP-OP.

Surat Perintah Penyitaan berpengaruh signifikan terhadap penerimaan PPh pasal 25 WP-OP pada KPP Gresik Gresik Utara yang ditunjukkan dengan hasil nilai sig sebesar 0,000. Nilai sig $<0,05$ menunjukkan bahwa Penerbitah Surat Perintah Penyitaan berpengaruh signifikan terhadap Penerimaan $\mathrm{PPh}$ pasal $25 \mathrm{WP}-\mathrm{OP}$.

\section{DAFTAR PUSTAKA}

DDTC. (2017). Pengertian dan Perhitungan PPh pasal 25. Dipetik April 7, 2018, dari Pengertian dan Perhitungan PPh pasal 25: Http://news.ddtc.co.id

Dirjen Pajak. (2015). Penagihan Pajak. Dipetik April 8, 2018, dari Http://www.pajak.go.id/content/256-penagihan-O-

Republik Indonesia (2009). Undang-undang no.16 tahun 2009 tentang ketentuan umum perpajakan.

Dirjen Pajak. (2012). Utang Pajak dan Penagihannya. Dipetik April 8, 2018, dari Http://www.pajak.go.id/content/seri-kup-utang-pajak-danpenagihannya

Republik Indonesia. 2000. Undang-undang no.19 tahun 2000 tentang penagihan pajak dengan surat paksa.

Republik Indonesia. 2008. Undang-undang no 36 tahun 2008 tentang pajak penghasilan.

Kukuh, S. D. (2014). Pengaruh Surat Ketetapan Pajak dan Tindakan Penagihan Pajak Terhadap Pencairan Tunggakan Pajak Penghasilan Badan. Vol. 17 No.1 Hal 1-8.

Derlina. (2013). Efektivitas Penagihan Tunggakan Pajak dengan Menggunakan Surat Paksa pada Kantor Pelayanan Pajak Pratama Manado. Vol. 1 No.4 Hal 1-11.

Mala, S. A. (2013). Analisis Efektivitas dan Kontribusi Tindakan Penagihan Pajak Aktif dengan Surat Teguran dan Surat Paksa sebagai Upaya PencairanTunggakan Pajak (Studi pada Kator Pelayanan Pajak Pratama Batu Tahun 2010-2012).

Rudi. (2013). Pengaruh Kualitas Penetapan Pajak dan Tindakan Penagihan Aktif terhadap Pencairan Tunggakan Pajak. Vol. 1 No.1 Hal 1-20.

Hendrawan (2014). Pengaruh Surat Paks terhadap Pencairan Tunggakan Pajak dan Impliksinya terhadap Penerimaan Pajak. Hal 1-17

Ulum, I., \& Juanda, A. (2016). Metodelogi Penelitian Akuntansi. Malang : Aditya Media Publishing.

Ghozali, I. (2016). Aplikasi Analisis Multivariete dengan Program IBM SPSS 23. Semarang: Badan Penerbit Universitas Diponegoro.

Mardiasmo. (2011). Perpajakan edisi revisi 2011 . Yogyakarta: C.V Andi Offset. Mardiasmo. (2016). Perpajakan edisi terbaru 2016. Yogyakarta: C.V Andi Offset. Zuraida, I., \& Advianto, L. H. (2011). Penagihan Pajak. Bogor : Ghalia Indonesia. niversitas Diponegoro. 